\title{
“Epidemiological Follow-up 15 Years After Presumably False Diagnoses of Breast Cancer" - A Statement by the German Senology Society
}

\section{„Epidemiologische Verlaufskontrolle 15 Jahre nach vermutlich falscher Diagnose Brustkrebs“ - Stellungnahme der Deutschen Gesellschaft für Senologie}

Authors

Affiliation
S. Becker ${ }^{1}$, M. Dietel $^{2}$, D. Wallwiener ${ }^{1}$

${ }^{1}$ Universitäts-Frauenklinik, Tübingen

${ }^{2}$ Pathologisches Institut Rudolf-Virchow-Haus, Campus Charité Mitte, Berlin
Bibliography

DOI http://dx.doi.org/

$10.1055 / \mathrm{s}-0031-1298542$

Geburtsh Frauenheilk 2012; 72:

523-524 @ Georg Thieme

Verlag KG Stuttgart · New York . ISSN 0016-5751

\section{Correspondence}

Prof. Dr. med.

Diethelm Wallwiener

Universitäts-Frauenklinik

Calwerstraße 7

72076 Tübingen

diethelm.wallwiener@

med.uni-tuebingen.de
In 1996 a suspicion arose with regard to a group of patients in Essen diagnosed with breast cancer. It was suspected that a certain pathologist was making incorrect diagnoses, that carcinomas were being diagnosed in cases where no oncological disease was present. When the findings of the pathologist under suspicion were rechecked, the diagnoses initially appeared plausible; however, DNA analysis showed that the pathologist in question had - clearly in an attempt at deliberate deception - presented false histological sections and tissue specimens.

The extent of the pathologist's misconduct, which was gradually emerging, led to an investigation by the Public Prosecutor's Office. A fire broke out in the pathologist's laboratory which appeared to have been started by the pathologist himself. The accused pathologist met his death in the fire and all patient records were lost, which made it impossible to subsequently correct any individual diagnoses and reassure any of the patients affected.

In view of the facts there can be little doubt that the pathologist behaved culpably, even though precise information cannot be obtained about the number of cases in which an incorrect diagnosis of "breast cancer" was made, either deliberately or due to negligence.

The current article by Hauth et al. presents data from the 15-year follow-up of the affected women and compares this data with the expected data of women who were correctly diagnosed with breast cancer. The study once again confirms that it is very probable that the majority of women who were diagnosed with breast cancer by the pathologist at the time and who subsequently underwent treatment in the form of operative intervention, chemotherapy or hormone therapy did not have oncological disease. It was found that the survival rates of patients in Essen were much higher compared to the rates for a comparable collective of patients with breast cancer.
1996 ergab sich in einer Gruppe von Mammakarzinompatientinnen aus Essen der Verdacht, dass von einem bestimmten Pathologen Fehldiagnosen gestellt wurden: Dass Karzinome diagnostiziert wurden, wo tatsächlich keine onkologische Erkrankung vorlag. Als die Befunde des unter Verdacht stehenden Pathologen überprüft wurden, schienen die Diagnosen zunächst plausibel, eine DNA-Analyse ergab aber, dass von dem betroffenen Kollegen - offensichtlich in dem Bemühen gezielter Täuschung - falsche Schnitte und Gewebsblöcke vorgelegt worden waren.

Das Ausmaß des sich abzeichnenden Fehlverhaltens führte zu staatsanwaltlichen Ermittlungen. Durch einen wohl selbst gelegten Brand im betroffenen Pathologielabor, in dem der angeklagte Kollege den Tod fand und alle Unterlagen verloren gingen, wurde eine nachträgliche Korrektur der Diagnosen im Einzelfall zur Beruhigung der Patientinnen unmöglich.

An dem schuldhaften Verhalten des Pathologen bleibt in der Zusammenschau der Fakten wenig Zweifel, wenn auch der exakte Nachweis, in wie vielen Fällen fahrlässig oder vorsätzlich eine falsche Diagnose „Mammakarzinom“ gestellt wurde, nicht mehr geführt werden kann.

Der vorliegende Artikel von Hauth et al. stellt das 15-Jahres-Follow-up der betroffenen Frauen vor und vergleicht diese mit dem zu erwartenden Follow-up bei Frauen, die tatsächlich eine histologische Diagnose „Mammakarzinom“ hatten. Erneut bestätigt sich, dass bei der Mehrheit der damals mit Brustkrebs diagnostizierten und entsprechend operativ und mit Chemo- bzw. Hormontherapie behandelten Frauen mit großer Wahrscheinlichkeit keine onkologische Erkrankung vorlag: Es zeigt sich ein deutlich besseres Überleben der Essener Patientinnen gegenüber einem Mammakarzinom-Vergleichskollektiv.

Die Deutsche Gesellschaft für Senologie ist dankbar, dass diese ungeheuerlichen und glücklicherweise einzigartigen Ereignisse durch das wissen- 
The German Senology Society is grateful that this scientific follow-up of the affected women means that this monstrous and luckily unique event has not been forgotten. The case goes to the heart of the medical profession: it strikes at the trust our patients place in us and the trust that medical colleagues place in each other.

Every day we take life-changing decisions together with and on behalf of our patients. More than in other social areas we depend on the accurateness of the facts available to us and the correctness of the information we use to make these decisions.

Interdisciplinary work depends on communication and communication depends on trust: trust in the proven competence of our partners and trust that the quality control systems which serve the interest of the patients entrusted to us will quickly flag up any issues.

Criminal intent of the sort displayed in the case above - whatever the motives were for these acts - only serves to emphasise the value of trust - and the true meaning of the old saying "trust is good - control is better".

The efforts of the German Senology Society and the German Cancer Society to systematise and centralise the diagnosis and therapy of the most common malign tumours affecting women, to ensure that the attending physicians who treat patients are competent, and to guarantee the quality of the interdisciplinary chain of competence through regular external controls must be seen against this background. These are the core elements of the extraordinarily successful certification of German breast centres according to DKS/DGS, a certification which is considered internationally as exemplary.

Our patients are entrusted to our care. The consistently high standards of quality demanded of breast centres, the safeguarding of highly relevant diagnoses by internal peer review, and the constant statistical evaluation all aim to protect our patients. But they also protect us as physicians working within a network of professional trust from such incalculable vagaries, which in the case discussed here brought harm to many women in an unprecedented manner. schaftliche betreute Follow-up der betroffenen Frauen nicht in Vergessenheit geraten. Der Fall berührt den Kern des ärztlichen Berufs: Das Vertrauen unserer Patientinnen zu uns und das Vertrauen ärztlicher Kolleginnen und Kollegen untereinander.

Jeden Tag fällen wir lebensverändernde Entscheidungen mit und für unsere Patientinnen. Mehr noch als in anderen gesellschaftlichen Bereichen zählen die Genauigkeit der uns zur Verfügung stehenden Fakten und die Korrektheit der Informationen, mit denen wir diese Entscheidungen fällen.

Interdisziplinarität bedingt Kommunikation, und Kommunikation braucht Vertrauen: Vertrauen in die nachgewiesene Kompetenz der Partner sowie Vertrauen in Kontrollsysteme, die zeitnahe Qualitätssicherung zum Wohle der uns anvertrauten Patientinnen gewährleisten.

Kriminelle Energie wie im o.g. Fall - aus welchen dunklen Motiven auch immer gespeist - verdeutlicht nur den Wert des Vertrauens - und den Sinn der alten Wahrheit „Vertrauen ist gut Kontrolle ist besser".

Vor diesem Hintergrund sind auch die Bemühungen der Deutschen Gesellschaft für Senologie gemeinsam mit der Deutschen Krebsgesellschaft zu sehen, die Diagnostik und Therapie des häufigsten bösartigen Tumors der Frau zu systematisieren, zu zentralisieren, die Kompetenz der behandelnden Ärzte abzusichern und die interdisziplinäre Kompetenzkette durch regelmäßigen externen Review in ihrer Qualität zu garantieren. Die Einführung der QuiP-Initiative (Qualität in der Pathologie) durch die Deutsche Gesellschaft für Pathologie und den Bundesverband Deutscher Pathologen ergänzt die Maßnahmen der Qualitätskontrolle. Dies sind die Kerninhalte der außerordentlich erfolgreichen und international als beispielgebend betrachteten Zertifizierung von Brustzentren nach DKS/DGS.

Unsere Patientinnen sind unsere Schutzbefohlenen. Die in den Brustzentren konsequent eingeforderte Qualitätskontrolle, die Absicherung hochrelevanter Diagnosen durch internen Peer-Review sowie die stetige statistische Evaluation soll diese, unsere Patientinnen schützen. Sie schützt aber auch uns als behandelnde Ärztinnen und Ärzte im Netz des kollegialen Vertrauens vor den Unwägbarkeiten, die im vorliegenden Fall auf beispiellose Weise Schaden über viele Frauen gebracht haben. 